\title{
Underemployment in View of Human Resource Management: Situational Analysis Scenario of Well-Educated People in Pakistan
}

\begin{abstract}
Dr. Muhammad Jawad ${ }^{a^{*}}$, Dr. Munazza Naz ${ }^{\mathrm{b}}$, Mr. Nauman Waheed ${ }^{\mathrm{c}}$, Dr.

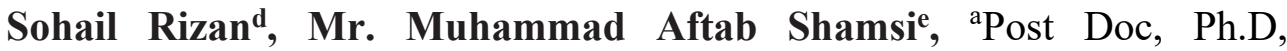
Department of Commerce, Fatima Jinnah Women University, Pakistan. *Corresponding Author, bPost Doc, Ph.D, Department of Mathematics, Fatima Jinnah Women University, Pakistan. ${ }^{\mathbf{c}, \mathbf{d}}$ Department of Commerce, Fatima Jinnah Women University, Pakistan. eUniversity Institute of Management Sciences, PMAS-Arid Agriculture University, Rawalpindi, Pakistan. Email: $\quad{ }^{a^{*}}$ muhammadjawad85@yahoo.com, bmunazzanaz@fjwu.edu.pk,_ crnauman_acc@yahoo.co.uk, dsohaildotrizwan@gmail.com, ${ }^{\mathrm{d}} \mathrm{chaftabshamsi@gmail.com}$
\end{abstract}

Underemployment is related with both business management and human resource management. Since situational and demanding conditions have considerable potential to make critical impact on both behavior and performance of people. The purpose of this study is to define the key variables of underemployment and both the causes and consequences of unemployment in the context of Pakistan.In this research, we trying to find the pre and post factors of underemployment. In this research situational analysis, descriptive Analysis and Multiple Regression Analysis is used. The data is collected through questionnaires from all over Pakistan. The sample size is consisting of 10000 individuals and response was 8691. The research found from results that Job opportunities, corruption, inflation and political instability have negative (inverse) impact on underemployment and terrorism has positive (increasing) impact on underemployment. Underemployment has negative impact on job opportunities, inflation, corruption; political instability and positive effect on terrorism. Meanwhile Criminal activities, frustration; suicide and brain drain have negative impact on underemployment.

Key words: Business Management; Human Resource Management; Situational Analysis; Education; Underemployment. 


\section{Introduction}

Society is affected by its own people. People influence communities with their behavior. People shape their community with their behavior, personality, and produce. Every people have potential to make effect on his community. For this reason, behavioral science should be integrated with business management and strategy related issues. To achievement objectives business consider their local society in view of their potential impacts. Underemployment people have family who has employ people. So, they are linked with each other.

Under-employment means "the underutilization of labor". It has three different applications; the employment of workers with highly skill in a low wage, involuntary part time workers and due to socio-legal restrictions, and seasonal work. However, there are many definition with define different aspect of underemployment like a job which you do as a part time and temporary kind of job which have a high level of uncertainty.

In Pakistan, a large proportion of employed labor force works less than $\mathbf{3 5}$ hours a week, therefore be considered as underemployed but only if they are willing to avail additional work. You can find that problem in each type of class in the society. It is also seen in skilled, semiskilled and unskilled workers or job holder (Fields, 1972).

The term underemployment indicates, by different measures is that the proportion of underemployed at national level is very small. It is almost 5 labor out of 100 labors. This data consisting of self employed, family supported etc. Qualified people are searching for a better job to enhance their skills, experience and capabilities. They try to find a shortcut for their better future but when they did not achieved it, a situation came which is known as a term underemployment. This problem enhance with the level of education. The expectation made them un-happy, worry about their carrier, difference between dream outcomes etc which cause them for searching and searching an ideal job (Rapten, 2014).

In the literature several reasons of underemployment are underpinned including job opportunities, corruption and terrorism. Other factors that are meaningful in this regard are political instability and inflation. On the consequences of the underemployment the existing literature reveals that frustration, brain drain, suicide and criminal activities are growing in the economies along the globe. It has also affected the health of the business. The situation of underemployment is vastly growing in Pakistan and highly qualifies youth is working in very small business entities to earn their livelihood.

In this research, we trying to find the pre and post factors of underemployment; Underemployment in Pakistan is situational analysis. Through this we came across the different definitions and current situation which prevails in economy. There is not a competitive research 
find about the underemployment in Pakistan. There is a huge gap which must be filled by researchers in present and future.

Considering such situation of the economy, in this paper we are studying the impact of underemployment on the society, after finding out the main causes of underemployment in the highly qualified and skilled labor. The main objective of the study are to find out the main factor that causes underemployment in the economy, to find out the socio-economic upshots that underemployment creates in the society and to do a situational analysis of the severity of increasing underemployment in well educated individuals and its ultimate impact on the psycho state of the individuals and the society.

In this research addresses following major questions that we face during the preliminary information collection; the causes of underemployment, its impact on Pakistan and consequences as frustration and criminal activities in the young generation in Pakistan.

\section{Literature Review}

The review of existing literature reveals that underemployment has many different aspects and measurement issues. ILO in (1998) defined and measured underemployment for the first time. The main character defined in international conference of labor statistician in the year 1925 is that if any person want more work and have less work then it desired, he/she is nominated as underemployed

Robinson (1936) defined the underemployed person as one who is laid off from the industries due to lack of labor demand and willing to do a lower cadre job. Robinson and Abbasi Z. (1979) try to find the factors which are invisible in nature or visible first for the case of underemployment in Pakistan. They have highlighted many measurement issues of the underemployment using different definitions of the term. They find underemployment low due to emphasize in agriculture. Fajnzylder et al. (2000) and Siphambe (2003) have addressed basic methodological issues of the defining underemployment, using different techniques.

The effect of crime on underemployment is defined by Ehrlich in (1973). In his point of view, underemployment is created due to low income and less job opportunities in the market. So criminal activities are increases parallel by the underemployment.

Callero (1994) defined the underemployment term that Workers do not simply look for hours, income, and opportunities for skill use when entering the labor market. Jobs also provide people with the opportunity to claim certain statuses in society. Burris (1983) found that many underemployed college graduates felt they were denied the high-status positions that their education should have afforded them. 
According to the latest labor force survey 1996-1997, the labor force participation rate of male is higher than females. The underemployment rate is very high among youth and educated professionals. Underemployment is also very high among very young people who worked in the household's production unit in the rural and urban informal economy.

Feldman, Leana and Turnley (1995-1997) define underemployment usually refers to a lower quality of employment relative to some standard of comparison. Clogg (1979) is defined in the labour utilization framework the term underemployment, of the adequacy of the exchange within the labor market between the household (usually operational as individual worker's hours and income) and the economy, and fairness is the criterion used to determine the adequacy of the exchange.

The cost-benefit approach is used by Becker (1962) for the analysis of the unemployment and underemployment. Another study by The Smith Family (an Australian Welfare Organization)(2003) found three major causes of youth underemployment: (i) shrinking job market, (ii) part-time education and job, and (iii) the youth turnover in the job market is also increasing.

Ummuhan Bardak describe in (2005) that well educated labor with higher qualification is a resource and a type of future investment in a developing countries which outcomes are very long-term in economics point of view. Ummuhan also describe it that through highly skilled labor the foreign investor are attract and this investment is like a investment in research \& development. It is viewed that brain drain is common in developing nations which create a problem on their economic growth. Pakistan has very low proportion of educated and highly qualified people among the whole population and they also want to emigrate in well developed nation for their better future.

Frustration is defined by Ted Robert Gurr in (1994) is that a basic source in which a person is totally confused upon any situation and the uncertainty level became so high and it is reflected as an anger. The person is fully hostile by that scenario and he/she don't see any way out from that problem.

Siphambe (2003) explored the issues of underemployment. The study showed that most important determinant of employment are age, gender and training. The probability of being employed increased by about 0.082 for female as compared to male. Age generally influenced the probability of employed in a positive manner. As age increased, the chances of being unemployed decreased. As expected, education has significantly enhanced the chances of being employed. Education has a negative and significant coefficient, implying that those who were more educated were more likely to be openly unemployed than to be underemployed. After reviewing of many studies on crime, it is commonly observed that there is a strong relationship of crime among underemployment and it is a main reason through which underemployment increase the world crime rate. 
Christopher Matgouranis describe the underemployment status in US and describe 17 million of American with Graduated degree are unemployed. A research study is conducted by Tony Cassidy and LizWright in 2008 over a time period of 1.5-2.0 year. The study contains a sample size of 248 people which are qualified as graduates and post graduates. They finding is about the mental and psychological stress, their health and their motivation level. They find that unemployment and underemployment deadly effect on these factors and their motivation level is too low, they are not much confident about their future and the want social support.

Krishna in (1973) addressed the basic methodological problem of defining underemployment in rural economies. Krishna identifies four different criteria commonly used to classify people as underemployed; Time criterion, Income criterion, Willingness criterion and Productivity criterion.

From all over the world, we find extensive amount of information, data and literature is assessable for analysis on underemployment different aspects. Review of literature is important because it highlights the problem under study. Research and scientific studies have to take guidelines from the previous work done in related fields. In these, not only view of economists on underemployment will be discussed but economists view on consequences relation of underemployment with respect to corruption, crime, suicides and population will be also seen. Pakistan is confronted with the problem of underemployment, which compounded by the increasing number of persons entering the labor market and low number of job opportunities being created in agricultural and industrial sectors.

\section{Data and Methodology}

Data was collected from the educated people from all over the Pakistan. Different tools had been used to collect data i.e. Primary data was collected through questionnaire and survey technique while secondary data was collected through different websites, different articles published in magazines, Books and Newspapers. Data was collected through telephonic interview, survey and questionnaires. The sample contains of 10000 individual and the responses were 8691 individuals. For data analysis Descriptive Statistics and Multiple Regression Analysis was used.

\section{Research Variables:}

\section{Explanation of variables:}

In this study of Causes and consequences, we will investigate the relationship of underemployment with Job Opportunities, Corruption, and terrorism on the cause side, whereas with Suicide, Criminal activities, Brain drain and Frustration on the consequences side. Political instability and inflation are also major indicators of the study. 


\section{Underemployment:}

Underemployment occurs when a worker is employed in a job in which he/she is not satisfied. There are different factors which are the responsible of underemployment in Pakistan. From elimination of these effects of those variables will help in reduction of underemployment.

\section{Job opportunities:}

Lack of job opportunities can cause the underemployment. It has adverse effect on underemployment. Pakistan is an under developing state has no industrial scale to appoint educated class on nation to their deserved post. There are lots of talented people who are striving to find right kind of job, but land up wasting their energy in inferior kind of job. Market trend also another reason for lack of job opportunity.

\section{Corruption:}

Every bad act or bad behavior is thus linked to and/or termed as corruption. These acts also cause of unemployment and underemployment. Corruption also includes personal references. It is a common phenomenon in our society that a person with better personal relations is enjoying more benefits than he/she deserves.

\section{Terrorism:}

Terrorism has placed wall on the road of our national economy. It has seized any international investment and development. It has seized any international investment and development. In this research, it is defined that terrorism is a cause of increasing unemployment and underemployment. People are frustrated and also it create a bad impact on foreign direct investment.

\section{CONSEQUENCES:}

\section{Brain drain:}

Brain drain is factor through which highly qualified and educated people are motivated to emigrate in developed countries for their future and better out comes. It is observed that through this factor round about $10 \%$ of highly skilled labor emigrated which create a negative impact on the country economy of developing countries and decrease their economic growth as well. is a huge investment by that country which is a great loss for that country if the move away in some another country like migration, work etc. Its also effect on foreign direct investment and research \& development of these nations and their investment in human development are failed to effect positively on economic growth. 


\section{Frustration:}

The condition in which a person is fully depresses and don't know what to do is called frustration. This condition is very common and mostly it is commonly seen in female rather then male.

\section{Suicide:}

Suicide is an activity in which a person lose its all hopes, find nothing, darkness everywhere at last he/she decide to select easy way and the only way to get out from these problems is to finish his/her life.

\section{Criminal activities:}

The alternative to gain some thing and the short cut for achieving many thing. When a person don't get his right legally, he/she is going for illegal things which is called criminal activities like smuggling etc through increase in underemployment rate, criminal activities are increased and legal rules, obligations are decreased.

\section{Data analysis:}

\section{Equations of Multiple Regression Analysis:}

$Y_{\text {U.E }}=\beta_{0}+\beta_{1} X_{\text {J.o }}+\beta_{2} X_{\text {CURUP }}+\beta_{3} X_{\text {TERR }}+\beta_{4} X_{\text {INF }}+\beta_{5}$ XP.I $+\varepsilon$

$\mathrm{Y}_{\mathrm{U} . \mathrm{E}}=$ Underemployment

$\mathrm{X}_{\mathrm{J} . \mathrm{O}}=$ Job opportunities

$\mathrm{X}_{\mathrm{CURUP}}=$ Corruption

$\mathrm{X}_{\mathrm{TERR}}=$ Terrorism

$\mathrm{X}_{\mathrm{INF}}=$ inflation

$\mathrm{X}_{\text {P.I }}=$ political instability

$\boldsymbol{\varepsilon}=$ other factors

$Y_{J . O}=\beta_{0}+\beta_{1} X_{U} . \mathbf{E}+\varepsilon$

$\mathrm{Y}_{\mathrm{J} . \mathrm{O}}=$ Job opportunities

$\mathrm{X}_{\mathrm{U} . \mathrm{E}}=$ Underemployment

$Y_{\text {CURUP }}=\beta_{0}+\beta_{1} X_{\text {U.E }}+\varepsilon$ 
$\mathrm{Y}_{\mathrm{CURUP}}=$ Corruption

$\mathrm{X}_{\mathrm{U} . \mathrm{E}}=$ Underemployment

$\mathrm{Y}_{\mathrm{TERR}}=\beta_{0}+\beta_{1} \mathrm{X}_{\mathrm{U} . \mathrm{E}}+\varepsilon$

(iv)

$\mathrm{Y}_{\mathrm{TERR}}=$ Terrorism

$\mathrm{X}_{\mathrm{U} . \mathrm{E}}=$ Underemployment

$\mathrm{Y}_{\mathrm{INF}}=\beta_{0}+\beta_{1} \mathrm{X}_{\mathrm{U} . \mathrm{E}}+\varepsilon$

$\mathrm{Y}_{\mathrm{INF}}=$ Inflation

$\mathrm{X}_{\mathrm{U} . \mathrm{E}}=$ Underemployment

$Y_{P . I}=\beta_{0}+\beta_{1} X_{U . E}+\varepsilon$

$Y_{P . I}=$ Political instability

$\mathrm{X}_{\mathrm{U} . \mathrm{E}}=$ Underemployment

$Y_{U . E}=\beta_{0}+\beta_{1} X_{C . A}+\beta_{2} X_{F R U S}+\beta_{2} X_{\text {SUC }}+\beta_{3} X_{\text {B.D }}+\varepsilon($ vii $)$

$\mathrm{Y}_{\mathrm{U} . \mathrm{E}}=$ Underemployment

$\mathrm{X}_{\mathrm{C} . \mathrm{A}}=$ criminal activities

$\mathrm{X}_{\mathrm{FRUS}}=$ Frustration

$\mathrm{X}_{\mathrm{SUC}}=$ Suicide

$\mathrm{X}_{\mathrm{B} . \mathrm{D}}=$ Brain drain

$\boldsymbol{\varepsilon}=$ other factors

\section{DESCRIPTIVE ANALYSIS}

This research majorly consists of adolescence ranking from age 21 to 25 . Questionnaire was filled by 20 to 60 year of age. Respondents having age from 20-25, 26-30, 31-35, and 35\& above were 1860, 3450, 1571 and 1810 in number respectively. Moreover, research was not specified to specific gender. This research views of both genders (male/female). $24 \%$ were female while $76 \%$ questionnaires were filled by males.

All the respondents have more education then intermediate. $40 \%$ respondents have education of 2 year bachelor's degree, $8 \%$ people did their bachelors (Hons), $45 \%$ of the respondents 
International Journal of Innovation, Creativity and Change. www.ijicc.net

Volume 15, Issue 6, 2021

have education of Master level and 5\% were MS/ MPhil and 1\% were PhD doctors. So we can say our research is applied on highly educational people.

Among the sample 4\% people had no working experience, $4 \%$ people have less than 6 months experiences. Among 870 of sample size, $10 \%$ people are doing job more then 6 months and less then 1.5 year. $36 \%$ people are those who are experiencing job more then 2 year but less then 5 year. This shows most of sample is employed. While 25\% persons are those are serving their services more than 5 years and $22 \%$ persons are those are serving more than 10 years.

\section{Results and Interpretation}

Through multiple regression test on Equation (i), the results are defined that

$U E=3.38-0.0478(J O)-0.0916(C)+0.0822(T)-0.0436(I)-0.0143(P ~ I)$

Table 1 Regression Analysis

\begin{tabular}{|l|l|l|l|l|}
\hline Predictor & Coefficient & S.D & T & P-value \\
\hline Constant & 3.3754 & 0.1842 & 18.33 & 0.000 \\
\hline JO & -0.04781 & 0.03573 & -1.34 & 0.018 \\
\hline C & -0.09158 & 0.03337 & -2.74 & 0.006 \\
\hline T & 0.08223 & 0.02477 & 3.32 & 0.001 \\
\hline I & -0.04360 & 0.02767 & -1.58 & 0.011 \\
\hline P I & -0.01427 & 0.02629 & -0.54 & 0.028 \\
\hline
\end{tabular}

$\mathrm{S}=0.7774 \quad \mathrm{R}$ Square $=0.867 \quad \mathrm{R}$ Square $($ adjusted $)=0.752$

In this model underemployment is dependent variable, whereas job opportunities, corruption, terrorism, inflation and political instability are independent variables.

The estimated results show that the first coefficients of these results indicate that there is inverse relation between job opportunities and underemployment. Similarly the coefficient of corruption shows that with an increase of one percent in corruption the underemployment decrease 0.09 percent. The coefficient of terrorism indicates increase of $1 \%$ in terrorism increase underemployment $0.08 \%$. The coefficient of inflation indicates increase of $1 \%$ in inflation the underemployment decrease 0.04 percent. The coefficient of political instability indicates increase of $1 \%$ in political instability decrease underemployment $0.01 \%$. The $t$-stat and the probability value indicate that job opportunities, corruption, terrorism inflation and 
International Journal of Innovation, Creativity and Change. www.ijicc.net

Volume 15, Issue 6, 2021

political instability results are significant because p-value is less than $5 \%$ alpha. R-squared explain $86.7 \%$ of variation of independent variables on dependant variable Equation (ii), after analysis it is describe that

$\mathrm{JO}=3.78-0.0705 \mathrm{U} E$

Table 2 Regression Analysis

\begin{tabular}{|l|l|l|l|l|}
\hline Predictor & coefficient & S.D & T & P value \\
\hline Constant & 3.7815 & 0.1027 & 36.81 & 0.000 \\
\hline U E & -0.07048 & 0.03342 & -2.11 & 0.035 \\
\hline
\end{tabular}

$\mathrm{S}=0.7756 \quad \mathrm{R}$ Square $=0.79 \quad \mathrm{R}$ Square $($ adjusted $)=0.62$

In this model underemployment is dependent variable, whereas job opportunity is the independent variable.

The estimated results show that the first coefficients of these results indicate that there is inverse relation between job opportunities and underemployment, which shows that $1 \%$ increase in job opportunities decrease underemployment $0.0705 \%$. The t-stat and the probability value indicate that job opportunities results are significant because p-value is less the 5 percent level of significance. R-squared explain $79 \%$ of variation of independent variables on dependant variable, which with the help of $\mathrm{F}$ test confirms that whole model is significant.

Equation (iii), it is summarize that

$\mathrm{C}=4.01-0.125 \mathrm{U} E$

Table 3 Regression Analysis

\begin{tabular}{|l|l|l|l|l|}
\hline Predictor & coefficient & S.D & T & P value \\
\hline Constant & 4.0108 & 0.1121 & 35.79 & 0.000 \\
\hline U E & -0.12492 & 0.03646 & -3.43 & 0.001 \\
\hline
\end{tabular}

$\mathrm{S}=0.8461 \quad \mathrm{R}$ Square $=0.64 \quad \mathrm{R}$ Square $($ adjusted $)=0.41$

In this model underemployment is dependent variable, whereas corruption is the independent variable. The estimated results show that the first coefficients of these results indicate that there is inverse relation between corruption and underemployment, which shows that $1 \%$ increase in corruption decrease underemployment $0.125 \%$. The t-stat and the probability value indicate 
International Journal of Innovation, Creativity and Change. www.ijicc.net

Volume 15, Issue 6, 2021

that corruption results are significant because p-value is less than alpha and significant at $5 \%$ alpha. R-squared explain $64 \%$ of variation of independent variables on dependant variable.

Equation (IV), to conclude

$\mathrm{T}=3.45+0.123 \mathrm{U} \mathrm{E}$

Table 4 Regression Analysis

\begin{tabular}{|l|l|l|l|l|}
\hline Predictor & coefficient & S.D & T & P value \\
\hline Constant & 3.4544 & 0.1434 & 24.09 & 0.000 \\
\hline U E & 0.12251 & 0.04665 & 2.63 & 0.009 \\
\hline
\end{tabular}

$\mathrm{S}=1.083 \quad \mathrm{R}$ Square $=0.83 \quad \mathrm{R}$ Square $($ adjusted $)=0.69$

In this model underemployment is dependent variable, whereas terrorism is the independent variable.

The estimated results show that the coefficient of these result indicate that there is positive relationship between terrorism and underemployment, which shows that $1 \%$ increase in job opportunities increase underemployment $0.12251 \%$. The $\mathrm{t}$-stat and the probability value indicate that terrorism results are significant at $5 \%$ alpha because $p$-value is small as 0.10 alpha. R-squared explain $83 \%$ of variation of independent variables on dependant variable

Equation (v), after the analysis

$\mathrm{I}=4.10-0.115 \mathrm{U} E$

Table 5 Regression Analysis

\begin{tabular}{|l|l|l|l|l|}
\hline Predictor & coefficient & S.D & T & P value \\
\hline Constant & 4.1020 & 0.1347 & 30.45 & 0.000 \\
\hline U E & -0.11517 & 0.04383 & -2.63 & 0.009 \\
\hline
\end{tabular}

$\mathrm{S}=1.017 \quad \mathrm{R}$ Square $=0.74 \quad \mathrm{R}$ Square $($ adjusted $)=0.54$

In this model underemployment is dependent variable, whereas inflation is the independent variable. The estimated results show that the coefficient of these results indicate that there is inverse relation between inflation and underemployment, which shows that $1 \%$ increase in inflation decrease underemployment $0.11517 \%$. The t-stat and the probability value indicate 
International Journal of Innovation, Creativity and Change. www.ijicc.net

Volume 15, Issue 6, 2021

that inflation results are significant at $5 \%$ of alpha because p-value is less than 0.05 of alpha value. R-squared explain $74 \%$ of variation of independent variables on dependant variable.

Equation (VI), It is reviewed that

$P I=3.58-0.0245$ U E

Table 6 Regression Analysis

\begin{tabular}{|l|l|l|l|l|}
\hline Predictor & coefficient & S.D & T & P value \\
\hline Constant & 3.5844 & 0.1367 & 26.21 & 0.000 \\
\hline U E & -0.02454 & 0.04449 & -0.55 & 0.018 \\
\hline
\end{tabular}

$\mathrm{S}=1.032 \quad \mathrm{R}$ Square $=0.80 \quad \mathrm{R}$ Square $($ adjusted $)=0.64$

In this model underemployment is dependent variable, whereas political instability is the independent variable. The estimated results show that the coefficient of these results indicates that there is no inverse relation between political instability and underemployment, which shows that $1 \%$ increase in political instability decrease underemployment by $0.02454 \%$. The tstat and the probability value indicate that the results are significant because p-value is small then 5 percent level of significance. R-squared explain $80 \%$ of variation of independent variables on dependant variable.

Equation (vii), It is examined that

$U E=3.62-0.0363(C A)-0.0248(F)-0.0601(S)-0.0565(B D)$

Table 7 Regression Analysis

\begin{tabular}{|l|l|l|l|l|}
\hline Predictor & Coefficient & S.D & T & P-value \\
\hline Constant & 3.6211 & 0.1661 & 21.80 & 0.000 \\
\hline CA & -0.03629 & 0.02867 & -1.27 & 0.0206 \\
\hline F & -0.02478 & 0.02474 & -1.00 & 0.033 \\
\hline S & -0.06007 & 0.02776 & -2.16 & 0.031 \\
\hline BD & -0.05654 & 0.02686 & -2.10 & 0.036 \\
\hline
\end{tabular}

$\mathrm{S}=0.7814 \quad \mathrm{R}$ Square $=0.93 \quad \mathrm{R}$ Square (adjusted) $=0.86$ 
In this model underemployment is dependent variable, whereas criminal activities, frustration, suicide and brain drain are consequences of underemployment.

The estimated results show that the first coefficients of these results indicate that there is inverse relation between criminal activities and underemployment. Similarly the coefficient of frustration shows that with an increase of one percent in underemployment will decrease frustration 0.02478 percent. The coefficient of suicide indicates increase of $1 \%$ in underemployment will decrease suicide $0.08 \%$. The coefficient of brain drain indicates increase of $1 \%$ in underemployment will decrease brain drain 0.05654 percent. The t-stat and the probability value indicate that the results are significant because $\mathrm{p}$-value is small. R-squared explain $93 \%$ of variation of independent variables on dependant variable.

\section{CONCLUSION AND POLICY IMPLICATION}

Through questionnaire technique, we came across that $56 \%$ people leading their lives in underemployed: while only $19 \%$ are well employed. Rests of people are either unemployed are doing self employment. Facts tell us that $68 \%$ of population is not satisfied with their income. $38 \%$ of respondent strongly agree while $21 \%$ agree that lack of job opportunities is a reason of over population, so it can be concluded that $59 \%$ believes that population is cause of underemployment. 68\% inquired and testified that inflation and high prices are reason of underemployment. One of the consequences of underemployment is social crime is verified by $65 \%$ of the population. $66 \%$ think anxiety and frustration as consequences of underemployment. $62 \%$ of population thinks underemployment is a cause of corruption.

With the help of questionnaire, we verified dependent variables of underemployment and consequences of underemployment. People's responses regarding our report is summed up in the following graph

\section{Graph 1 Cause \& Consequences of underemployment}

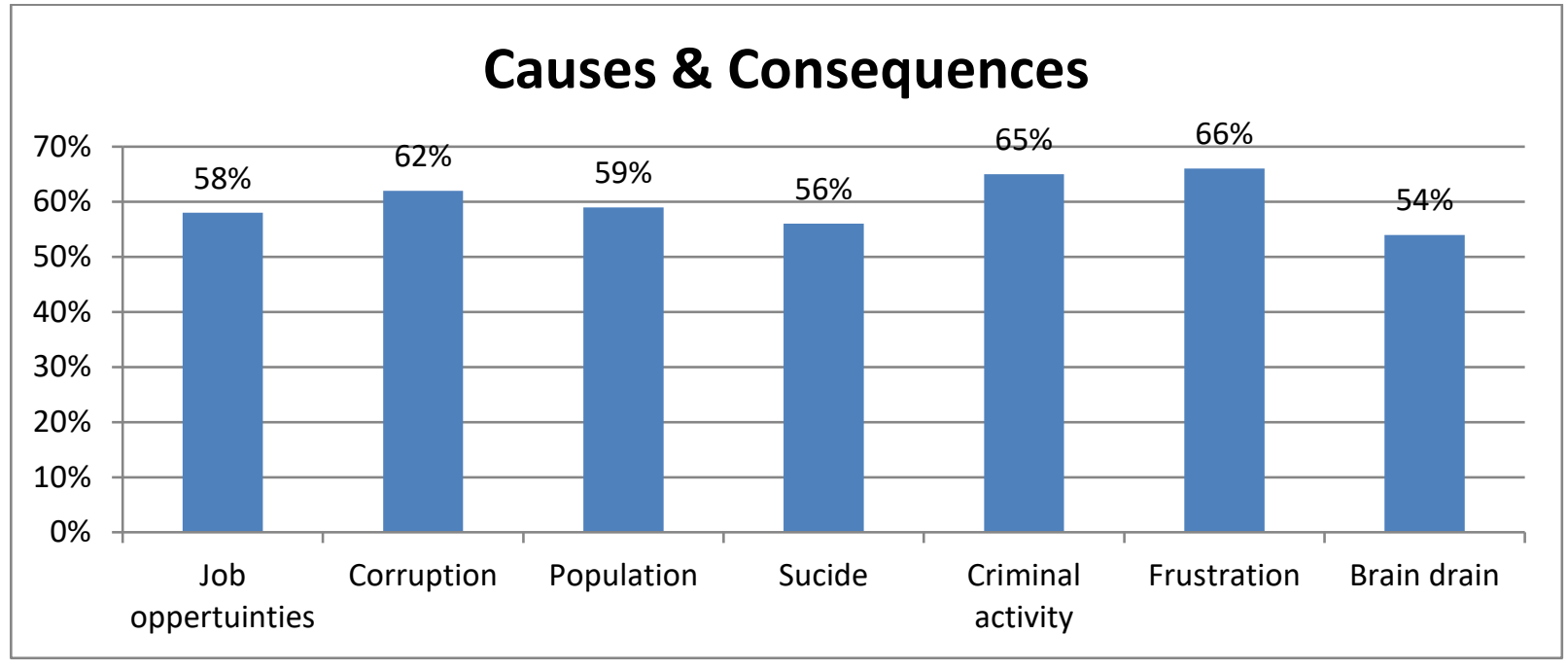


This research shows criminal activities have direct relation with the underemployment. $65 \%$ persons testify the existence of underemployment which may cause of criminal activities in Pakistan. In Pakistani scenario, Male is responsible to support all his family so it is observed that the rate of underemployment is relatively lower in males with respect to females.

The main cause of underemployment in Pakistan is that there is not proper counseling is available and provided to youth for their better carrier future which cause as students loose hope so frustration increases. Government, NGO's and no other institution provided any guidance to youth for their study and career which is a basic requirement and implemented in many countries across the world. In developed countries, the youth counseling is a key point of reduce their underemployment rate and through this, they focused on all departments which enhance their outcomes and created new avenues for future. Pakistan is much behind in this section.

Faulty structure of administration in urban areas is also cause of structural underemployment. Pakistan also not focused on that aspect and don't have that institutions which describe the skilled which is well-matched to your career and the market in present and future. This factor grooms the growth of economy. Underemployment is like a trail for our youth. Through Okun's law it is defined that if any country GDP is decreased by $2 \%$, it cause to increase the underemployment by $1 \%$. So when we implement in Pakistani scenario, we find that there is no stability in Pakistani economy throughout from 1947 due to miss management of resources and bad utilization of resources which cause of waste of these resources and economy never get it potential output.

It is observed that the wealth and resources are in a few hands in Pakistan and they are enjoying the luxurious living of life but remaining people are living miserable life and they are far behind of that luxurious life. These people are a large part of the whole population. When we comprise it a little more, it is find that in that specific group, the main effected people are the youth of our country which are totally dis-hearted because when they reached at market after completion of their study, they find the huge gap between their desired and offered outcomes or jobs. The low income level which are offered by the organization also cause of increasing underemployment.

\section{SUGGESTIONS \& STRATEGIES:}

To improve Pakistani economy and decrease the underemployment rate to gain the potential output, some immediate counter measures and corrective action must be taken. Following are some key point and suggestions which improved the governance.

Employment scheme must introduce in urban and rural areas to reduce unemployment and underemployment. Government enhances its operation SME which develop new venues and venture through which unemployment and underemployment decreased. 
The education system of Pakistan is not up date. New Challenges are not facilitate by these system and practical implication is also not countered by that system. So reviewed education system. Another drawback is that our education producing white collar employees on a large scale which is not according to our industry needs. Technical education and skilled labor is also a basic need of the industry. So government must focus on those sectors.

Self employment and entrepreneurship are the key strategies to decrease unemployment and underemployment but it is a paradox that our engineers, doctors, scientists, researchers etc are wanted and run for the government jobs.

Government should focus on vocational and technical education for making skilled labor according to the industrial and market needs.

To handle with new challenges, government should established more industrial areas and invest on developing expenditure which decrease the unemployment and underemployment.

Higher education commission of Pakistan reevaluates his education system according to future needs and demand and stop unsystematic admissions in universities and colleges.

Research significance can be seen if government pursues some strategies like national internship program (N.I.P). 
International Journal of Innovation, Creativity and Change. www.ijicc.net

Volume 15, Issue 6, 2021

\section{REFERENCES}

Becker, Gary S. (1962) -Investment in Human Capital: A Theoretical Analysis. Journal of Political Economy, 70, 9-49.

Becker, Gary S. (1968). Crime and punishment: An economic approach. Journal of Political Economy, 76(1), 169-217.

Bednarzik, R.W., (1975). Involuntary Part-Time Work: A Cyclical Analysis. Monthly Labor Review, 98(9), 12-18.

Burris, B. H. (1983). The human effects of underemployment. Social Problems, 31, 96-110.

Byrne, D. and E. Strobl, (2001). Defining Unemployment in Developing Countries: The Case of Trinidad and Tobago. CREDIT Working Paper, 1(9), University of Nottingham.

Callero, P. L. (1994). From role-playing to role-using: Understanding role as resource. Social Psychology Quarterly, 57, 228-243.

Cassidy, Tony and Liz Wright. (2008). Graduate Employment Status and Health: A Longitudinal Analysis of the Transition from Student. Social Psychology and Education $\begin{array}{lllll}\text {, (11). } & \text { Retrieved } & \text { March } & 7 & 2012\end{array}$ (http://www.springerlink.com/content/p55756654567266u/fulltext.pdf).

Clogg, C. C. (1979). Measuring underemployment: Demographic indicators for the United States. New York: Academic Press.

Ehrlich, I. (1973). Participation in Illegitimate Activities: A Theoretical and Empirical Investigation. The Journal of Political Economy. 81 (3), 521-565.

Fajnzylber, Pablo, Daniel Lederman and Norman Loayza (2000). Determinants of crime rates in Latin America and the world: Anempirical assessment. World Bank Latin American and Caribbean Studies.

Feldman, D. C. (1996). The nature, antecedents, and consequences of underemployment. Journal of Management, 22, 385- 407.

Feldman, D. C., \& Turnley, W. H. (1995). Underemployment among recent business college graduates. Journal of Organizational Behavior, 16, 691-706.

Feldman, D. C., Leana, C. R., \& Turnley, W. H. (1997). A relative deprivation approach to understanding underemployment. In C. L. Cooper \& D. M. Rousseau (Eds.), Trends on Organizational Behavior, 4, 43-60.

Fields, G. S. (1972). Rural-urban migration, urban employment and underemployment, and job search activity in LDCs [Electronic version]. Washington, DC: U.S. Agency for International Development.

Gurr, Tedd R.(1994). Early warning of communal conflicts and humanitarians crises. The Journal of Ethno-Development, 4 (1).

ILO, 1990, Surveys of Economically Active Population, Employment, Unemployment and Underemployment - An ILO Manual of Concepts and Methods, Geneva.

ILO, 1998, Unpublished Preliminary Report on the Resolution on Underemployment, Geneva: ILO. 
Krishna, R. (1973). Unemployment in India. Indian Journal of Agricultural Economics, 28, 1, $1-24$

Kristy Muir at.al (2003). Youth Unemployment in Australia. The Smith Family Report.

Lee, Y. Daniel (2002). Income Inequality and Crime: Cointegration Analysis and Causality Tests, Shippensburg University.

Rapten, Phuntsho. (2014). Understanding the Dynamics of Labour Market and Youth Unemployment in Bhutan- A study for policy and Strategic Responses. VRF series, 487(1).

Robinson, J. (1936). Disguised unemployment, Economic Journal, 46 (182), 225-37.

Robinson, W.C. and N. Abbasi (1979). Unemployment in Pakistan. The Pakistan Development Review, 28( 4), 313-331.

Siphambe, H.K. (2003). Understanding Unemployment in Botswana. South African Journal of Economics, 71(3), 480-95.

Stratton, L.S., (1994). Reexamining Involuntary Part-Time Employment. Journal of Economic and Social Measurement, 20(2), 95-116. 